\title{
Apresentação
}

\section{Dois pensadores da vanguarda literária e artística: Alfred Döblin e Walter Benjamin}

Walter Benjamin e Alfred Döblin - dois pensadores da vanguarda literária e artística na Alemanha. Ambos conheceram as inquietações de seu tempo, assumiram posturas críticas em relação ao fascismo alemão e, especificamente, ao nazismo. Ambos tiveram de fugir da Alemanha no início de 1933, após Hitler chegar ao poder, viveram anos de exílio durante o "Terceiro Reich", com estações pela Suíça, França e Estados Unidos, no caso de Döblin, e França, no caso de Benjamin, que, tragicamente, cometera suicídio em 1940, ao tentar atravessar a fronteira espanhola em Port Bou, nos Pirineus. Por assim dizer, Döblin teve melhor "sorte": conseguiu fugir em 1940 através da Espanha e de Portugal, onde embarcou para o exílio norte-americano, na cidade californiana de Santa Monica. Ao término da Segunda Guerra Mundial, retornou para a Europa.

Mas as relações entre ambos não param por aí: Döblin, um romancista por excelência, conhecido mundialmente por sua obraprima, o romance Berlin Alexanderplatz (1929), também se destacou pelos inúmeros ensaios que escreveu sobre teoria literária, política e cultura; Walter Benjamin desfruta do reconhecimento por inúmeros ensaios que se tornaram clássicos para se pensar conceitos como o de "história", "alegoria", "origem" etc., ou mesmo para se refletir sobre a "crise do romance" e da arte de narrar, fruto da pobreza de experiência transmissível.

Sem dúvida, ambos os pensadores foram marcados pela Primeira Guerra Mundial, que contou, inclusive, com a participação de Döblin enquanto médico neurologista em uniforme. O senso crítico de ambos, durante a República de Weimar e os anos de exílio, em relação à sociedade alemã e à produção artística e literária, resulta de uma leitura aguçada e atenta das convulsões políticas vivenciadas pelo país com o fim do Império, a Revolução de 1918 e a instauração da República, comprometida por elementos reacionários que insistiam em promover a instabilidade política, que culminará com a ascensão do nazismo ao poder. 
As contribuições que integram o dossiê "Dois pensadores da vanguarda literária e artística: Alfred Döblin e Walter Benjamin” e que compõe a presente edição, procuram refletir sobre a atuação desses escritores enquanto autênticos vanguardistas, cujas obras foram marcadas por características inovadoras e avançadas, mantendo sua atualidade, e nos fornecem conceitos, chaves de leitura e referencial teórico no âmbito dos Estudos Literários.

De início, Luiz Henrique Ernesto Coelho propõe uma abordagem comparada de dois ensaios em torno do conceito de história, buscando neles pontos de aproximação que revelam a congruência com o espírito de vanguarda: "O romance histórico e nós" (1938), de Alfred Döblin, e "Sobre o conceito de história" (1940), de Walter Benjamin.

Em seguida, Anna Flávia Dias Salles, baseando-se também em uma abordagem comparada, propõe uma análise dos procedimentos narrativos levados a cabo por Alfred Döblin no romance Berlin Alexanderplatz (1929) e, respectivamente, por Walter Benjamin na obra Infância em Berlim por volta de 1900 (1932-1933, 1980), de cunho memorialístico. Dentre tais procedimentos narrativos figurariam a montagem literária e a escrita fragmentária e errante.

Por sua vez, as demais contribuições que integram o dossiê dedicam-se a um desses dois pensadores enquanto referências para a reflexão de aspectos específicos. Izabela Baptista do Lago, por exemplo, propõe uma reflexão sobre o romance enquanto gênero literário, a partir de noções e conceitos teóricos propostos por Alfred Döblin em diversos ensaios publicados entre 1913 e 1930. A autora conclui em seu estudo que teorização e prática artística caminham juntas na obra de Döblin, atingindo sua plena concretização no romance Berlin Alexanderplatz.

Ao pensar a vanguarda europeia, em seguida, Carolina Izabela Dutra de Miranda enfoca aspectos específicos do futurismo russo a partir de considerações efetuadas por Walter Benjamin nos textos "A nova literatura Russa" (1927) e "O agrupamento político dos escritores na União Soviética" (1927). Segundo a autora, o futurismo russo ou cubofuturismo - se relacionaria com um movimento crítico a ele contemporâneo: o formalismo russo. Nesse sentido, Vladimir Maiakovski representaria um elo de ligação entre o movimento crítico do formalismo e o movimento vanguardista do cubofuturismo. 
Nas sendas de Walter Benjamin, Juliano Klevanskis Candido valese de noções e conceitos teóricos postulados pelo pensador berlinense, entre eles, "alegoria" e "narrativa", para analisar textos ficcionais da Literatura Israelense: os contos "O caminho do vento" e o "O nômade e a víbora" (1965), de Amos Oz, e o conto "O casamento de Gália" (1970), de Avraham B. Yehoshua.

Por fim, Derick Davidson Santos Teixeira propõe um trabalho comparado entre Walter Benjamin e Maurice Blanchot no que concerne à noção de escritura. Para o autor, ao operar "como um limiar (Schwelle)", a escritura escaparia "à rigidez das fronteiras que separam o pessoal e o histórico, a ordem comum do individualismo, a experiência da vivência".

A seção Varia apresenta dois artigos que contemplam a literatura brasileira. No primeiro, Renato Rocha de Oliveira e Elcio Loureiro Cornelsen abordam a influência de Diadorim sobre Riobaldo em Grande Sertão: Veredas, de João Guimarães Rosa, pela perspectiva filosófica do sublime e da coragem, valendo-se, para isso, de pensadores como Burke e Schiller. No segundo, Ivan Delmanto apresenta aspectos do processo histórico de formação da dramaturgia brasileira a partir dos conceitos de alegoria, messianismo e imagem onírica, provenientes de Walter Benjamin.

A resenha do livro de Bernd Witte, Walter Benjamin: uma biografia, elaborada por Luciana Araujo Marques, completa este número da revista. Lançado no Brasil em 2017, o livro foi publicado originalmente na Alemanha em 1985 e apresenta a trajetória intelectual de Benjamin a partir de seus ensaios, o que é descrito com detalhes na resenha.

Elcio Loureiro Cornelsen (UFMG) Rosani Úrsula Ketzer Umbach (UFSM) (organizadores) 